\title{
Grundtvigs politiske tanker i dag
}

\author{
Af Kim Arne Pedersen
}

Arne Busk Madsen: Folket og de intellektuelle. Forlaget Aros. Århus 1993. 114 s. $129 \mathrm{kr}$.

Grundtvig hører til de skikkelser i dansk åndsliv, der ikke blot behandles i en bog i ny og næ, men hvert år gøres til genstand for en række højst forskellige tolkninger. Ved siden af videnskabelige studier i dele af Grundtvigs forfatterskab udkommer en mængde bøger, der beskæftiger sig med Grundtvig ud fra en aktuel interesse i hans synspunkter. Grundtvigs tanker er levende, de har den gennemslagskraft også i dag, som er karakteristisk for de virkelig store forfatterskaber og ideer op gennem historien. Derfor vil ikke blot videnskabsmandens omhyggelige granskning i Grundtvigs skrifter, men også brugen af Grundtvig i den aktuelle debat have deres berettigelse. En sådan brug finder vi i den her omtalte bog, sognepræst Arne Busk Madsens sammenligning af Grundtvigs politiske tanker i tidsskriftet Danskeren med ideer hos tre $\emptyset$ steuropæiske politiske tænkere, Dostojevskij, Solsjenitsyn og Václav Havel.

Bogen besidder en række mangler i henseende til formen. Referaterne af Grundtvigs artikler fremtræder engang imellem, som om det er forfatterens, altså Busk Madsens kommentar til Grundtvig i stedet for en gengivelse af, hvad Grundtvig siger, ofte bliver der tale om sammenstilling af tanker fremfor analyse, der bringes citater uden fyldestgørende henvisning og litteraturlisten er upræcis. Det er imidlertid forhold, der kan ses bort fra, når det gælder bedømmelsen af bogens indhold.

Her bliver det fra begyndelsen klart, at der er tale om en aktuel debatbog. En del af bogen har tidligere været trykt som artikel i tidsskriftet Tidehverv og Arne Busk Madsens Grundtvig-læsning er da også beslægtet med de holdninger, man finder $\mathrm{i}$ den kreds af udgivere, der $\mathrm{i}$ dag tegner bevægelsen af samme navn. I indledningen knyttes til ved den engelske historiker Poul Johnsons fremhævelse af, at kristendommens filosofi om personligt ansvar er blevet svækket gennem det moderne, af Johnson identificeret med, hvad der vel må være de indirekte virkninger af Einsteins relativitetsteori samt Freuds dybdepsykologi, altså tanker, der er udtænkt af mennesker, der i kraft af deres tilhørsforhold til en (akademisk) elitegruppe er på afstand af den menige mand og som ifølge Busk Madsen opfatter mennesket som et bytte for kræfter snarere end et ansvarligt væsen. Det er Arne Busk Madsens intention at vise, at de fire behandlede tænkere alle kæmper mod den moderne tendens hos den intellektuelle elite til at betragte sig selv som bærer af de afgørende indsigter i en abstrakt humanisme, der opfattes som grundlaget for politisk arbejde og virksomhed. Den modsætning mellem folket og de intellektuelle, som har præget de sidste 200 års europæisk politik, ser Busk Madsen afspejlet $\mathrm{i}$ kommunismens virkelighedsfjerne og i virkeligheden elitære tænkemåde, men ikke blot i denne i dag stærkt svækkede ideologi, men også i De Europæiske Fællesskabers tro på Den europæiske Union som en overnational størrelse, der vil sætte nationalstaten ud af kraft.

Bogen er som før nævnt ikke tænkt som en videnskabelig studie i Grundtvigs politiske ideer. Alligevel forekommer det ind imellem læseren, at der mangler en dimension i bogen, nemlig den historiske dimension, som de næunte tænkeres 
baggrund i samtidens ideverden udgør. Selv om bogen er et indlæg i den løbende debat, og ikke et stykke videnskab, havde det været rimeligt at inddrage romantikken som baggrund for i hvert fald Grundtvig og Dostojevskij, men i høj grad også for Solsjenitsyn. En sammenligning af Dostojevskijs og Grundtvigs politiske tanker havde på sin vis været nok til at udfylde en videnskabelig undersøgelse, men også i det foreliggende værk burde det have været gjort klart, at lighederne mellem de to tænkeres politiske tanker om det folkelige, om den nationale identitet og det jævne, oprindelige folk som bærer af den sunde virkelighedsopfattelse ikke er tilfældig, men skyldes de romantiske tankers fascinationskraft i sidste århundredes vidt forskellige europæiske nationer. En sådan historisk dimension i bogen ville i virkeligheden også have lettet læserens tilegnelse af stoffet, idet de nævnte tænkeres ideer af Busk Madsen ofte indføres så brat, at læseren har vanskeligt ved at modtage de refererede tanker. Endvidere kunne det have været gavnligt for Busk Madsens behandling af Grundtvigs tanker om folkeånden ( $\mathrm{i}$ hvilken forbindelse han ud fra sin omhyggelige læsning er i stand til at kritisere Grundtvigforskningen), om denne behandling havde taget grundigere fat på det spørgsmål om forholdet mellem individet og det folkelige fællesskab som ledet af ånden, der trænger sig på, når man beskæftiger sig med de næunte motiver. En sådan grundig redegørelse kunne med fordel have taget udgangspunkt i romantikkens tanker om det kollektive, om folket som en organisme, at der er noget, der er større end det enkelte jeg, og at dette virkeliggør sig gennem folket. Samtidig må det siges, at forholdet mellem det enkelte jeg og det altomfattende ikke er et forhold, man gør sig færdig med i en hast. Og netop her er det, at de mest afgørende brudflader mellem de behandlede positioner kommer frem.

I bogens sidste kapitel kontrasterer Arne Busk Madsen Havel og Grundtvig. Busk Madsen gengiver Havels betænkeligheder ved den bølge af nationalisme, der forståeligt nok er skyllet ind over Østeuropa efter jerntæppets fald. For Havel udgør denne bølges kamp for national selvbestemmelse et problem, hvis den samtidig fører til afvisning af deltagelse i overnationale enheder, baseret på »borgerprincipper«, menneskerettigheder. Busk Madsen vender sig her imod Havels tro på, at en abstrakt tale om menneskehed og menneskerettigheder kan træde i stedet for den konkrete, folkelige, historiske virkelighed, der for Grundtvig danner basis for det politiske liv og dets beslutninger. Intet menneske kan overskue det endnu uafsluttede historieforløb, og derfor kan man ikke opstille principper, der tager højde for en hvilkensomhelst politisk situation og en hvilkensomhelst folkelig virkelighed. Kærlighed til medmennesket er nok udgangspunktet for samfundslivet, men den retter sig ikke mod den universelle menneskehed, men kan kun få skikkelse indenfor det særskilte, folkelige fællesskab, den enkelte tilhører. Busk Madsen fremhæver grundloven og folketinget som de urokkelige grundpiller i Grundtvigs forståelse af, hvorledes den enkelte nations suverænitet sætter sig igennem. I forbindelse med disse størrelser er det, som det fremgår af denne årgang Grundtvig Studier, muligt at grave ny viden frem om Grundtvigs politiske teorier. Det overskygger imidlertid ikke, at Busk Madsen har beskæftiget sig grundigt med artiklerne i Danskeren, og at han formår at lade Grundtvigs tanker indgå i en tankevækkende aktuel, politisk drøftelse. Som et indlæg i debatten, hvor Grundtvigs tanker tages som udgangspunkt, er Busk Madsens bog derfor en god udgivelse. 